\title{
Lack of Response of Old Coffee Trees Grown in Alonso Clay To Lime and Phosphatic Fertilization ${ }^{1}$
}

\author{
J. A. Bonnet, A. R. Riera, and M. A. Lugo-López ${ }^{2}$
}

\section{INTRODUCTION}

Lime applications to the acid tropical soils of Puerto Rico have been shown to be beneficial to sugarcane (1) ${ }^{3}$, forage crops (2), fiber crops (11), and such food crops as sweetpotatoes and corn $(4,11)$, but few results have been obtained with coffee. McClelland reported that no appreciable effects on the growth (12) or production (13) of coffee trees could be measured after liming an acid Catalina clay. Later studies by Guiscafré (5) and Guiscafré and Gómez $(6,7,8)$, made between 1936 and 1940, of two acid soils, indicated that limestone applications at rates of $3 / 4$ ton to 3 tons to the acre did not affect coffee yields in soils with $\mathrm{pH}$ values from 5.5 to 6.0. In soils with $\mathrm{pH}$ values from 4.0 to 4.5 , limestone applied at the rate of 1 ton to the acre produced significant yield increases, but 2,3 , or 4 tons did not.

Information regarding the fertilizer requirements of coffee is just as meager. McClelland reported (13) that potash application was essential for soils wherein coffee grows, but phosphorus was not. A report issued in 1946, by Gómez et al. (9) covering the results of a 6-year fertilizer test with 16-year-old coffee trees grown on a Catalina soil, emphasized the need of nitrogen and phosphorus, but not of potassium. Gómez' group also reported (9) that phosphorus applications were necessary for maximum yields in a 3 -year test with young coffee plants on the same soil type at Mayaguiez.

This paper reports data obtained from a 4-year experiment with old coffee trees that received lime and phosphatic fertilizers. The inherent limitations of this work are recognized and will be discussed.

1 Joint contribution of the Department of Soils, the Central Analytical Laboratory, and the Castañer and Gurabo Agricultural Experiment Substations.

2 Head of the Department of Soils, Associate Chemist in Charge of the Central Analytical Laboratory, and Associate Soil Scientist in Charge of the Gurabo Substation, Agricultural Experiment Station, University of Puerto Rico, Río Piedras, P. R. Appreciation is expressed to S. Rodríguez, Assistant Agronomist in Charge, and to J. Toro and L. Alemañy, Research Assistants in Agronomy, Castañer Substation, for their help in harvesting and supervising the fieldwork. J. Roldán, Assistant Chemist of the Soils Department, helped in the initial stages of the work. G. Malaret Juarbe, former Research Assistant in Chemistry, performed some laboratory analyses. Thanks are expressed to Compagnie Nord Africaine de L'Hyperphosphate Reno, 47 Rue de Liege, Paris, and to their agent, Bernard Carreau, at Fort de France, Martinique, for supplying the superphosphate.

${ }^{3}$ Italic numbers in parentheses refer to Literature Cited, pp. 166-7. 


\section{MATERIALS AND METHODS}

The experiment was located at the Agricultural Experiment Substation Farm in the vicinity of Adjuntas and Lares, which lies in the humid, mountainous heart of the Coffee Region of Puerto Rico. The soil is Alonso clay, a rather extensive acid ( $\mathrm{pH}$ 4.2) upland latosol derived from reddish-purple igneous rocks (15). In this soil feldspars of the oligoclase variety are in medium abundance in the fine sand and silt fractions, and kaolinite is the predominant clay mineral (10). The exchange capacity ranged from 20 to 40 m.e. per $100 \mathrm{gm}$. of soil, unusually high for latosols. The slope of the field ranged anywhere from 20 to 40 percent.

The experiment was laid out following a paired-plot design including 16 treatments: Two sources of phosphates-super- and hyperphosphate each was used at four rates, either with or without lime: $0,50,125$, and 200 pounds of $\mathrm{P}_{2} \mathrm{O}_{5}$ to the acre. A single tree represented a plot with an area of 8 feet by 9 feet; 1 acre contained 605 trees, probably between 10 and 15 years of age. Each treatment was replicated 15 times for a total of 240 trees in the experiment. Lime was applied to those plots requiring it according to the experimental design, at a rate of 4 tons to the acre (soil pH 4.2), April 14-17, 1953. The plots were fertilized May 21, 1953, with 108 pounds of nitrogen and 60 pounds of $\mathrm{K}_{2} \mathrm{O}$, on the acre basis, and phosphoric acid was determined by treatment differentials. The lime and fertilizer were evenly distributed in the canopy area. The three succeeding crops were fertilized as was the 1953-54 crop, but the lime applications were not repeated. The berries were harvested for four consecutive crop years and production figures are reported as marketable coffee by applying a standard conversion factor to the yield of coffee berries obtained.

A soil profile was sampled to a 6 -foot depth in the experimental area and the phosphate levels determined according to the Olsen bicarbonate method $(14)$.

\section{RESULTS AND DISCUSSION}

Table 1 presents data on yields of marketable coffee for four succeeding crops. Table 2 provides a direct and simple comparison of the coffee production by limed and unlimed plots. No significant differences were measured which could be attributed to either type or rate of phosphatic fertilizer, irrespective of the presence of absence of lime. Alonso soil is apparently

${ }^{4}$ A phosphatic fertilizer obtained from the North African sedimentary deposits of phosphate of lime. Chemical analyses revealed that hyperphosphate had an average content of 26-percent total $\mathrm{P}_{2} \mathrm{O}_{5}$ while the commonly used superphosphate has only 19 percent. The available $\mathrm{P}_{2} \mathrm{O}_{5}$, however, was only 5.9 percent in the hyperphosphate while almost all is available in the superphosphate. 
TaBLE 1.-Effect of phosphatic fertilizers applied to acid Alonso clay, in the absence or presence of lime, upon marketable coffee yields

\begin{tabular}{|c|c|c|c|c|}
\hline \multirow{2}{*}{ Treatment } & \multicolumn{4}{|c|}{$\begin{array}{l}\text { Mean }{ }^{1} \text { hundredweights per acre of coffee at indicated } \mathrm{P}_{2} \mathrm{O}_{5} \text { levels, } \\
\text { in pounds per acre }\end{array}$} \\
\hline & 0 & 50 & 125 & 200 \\
\hline \multicolumn{5}{|c|}{$1953-54$ crop } \\
\hline $\begin{array}{l}\text { Superphosphate } \\
\text { Hyperphosphate } \\
\text { Superphosphate plus lime } \\
\text { Hyperphosphate plus lime }\end{array}$ & $\begin{array}{l}7.22 \\
6.27 \\
7.56 \\
7.18\end{array}$ & $\begin{array}{l}5.98 \\
6.03 \\
6.59 \\
7.79\end{array}$ & $\begin{array}{l}6.50 \\
4.99 \\
6.81 \\
5.43\end{array}$ & $\begin{array}{l}7.60 \\
7.74 \\
6.59 \\
6.19\end{array}$ \\
\hline \multicolumn{5}{|c|}{$1954-55$ crop } \\
\hline $\begin{array}{l}\text { Superphosphate } \\
\text { Hyperphosphate } \\
\text { Superphosphate plus lime } \\
\text { Hyperphosphate plus lime }\end{array}$ & $\begin{array}{r}2.26 \\
1.38 \\
.78 \\
1.58\end{array}$ & $\begin{array}{l}1.63 \\
2.67 \\
1.49 \\
1.43\end{array}$ & $\begin{array}{l}1.70 \\
1.27 \\
1.80 \\
1.02\end{array}$ & $\begin{array}{l}1.50 \\
1.67 \\
1.18 \\
2.89\end{array}$ \\
\hline \multicolumn{5}{|c|}{$1955-56$ crop } \\
\hline $\begin{array}{l}\text { Superphosphate } \\
\text { Hyperphosphate } \\
\text { Superphosphate plus lime } \\
\text { Hyperphosphate plus lime }\end{array}$ & $\begin{array}{l}7.59 \\
6.87 \\
7.30 \\
4.56\end{array}$ & $\begin{array}{l}7.87 \\
6.99 \\
7.09 \\
6.96\end{array}$ & $\begin{array}{l}9.57 \\
5.50 \\
4.91 \\
6.86\end{array}$ & $\begin{array}{l}8.34 \\
7.17 \\
7.52 \\
3.59\end{array}$ \\
\hline \multicolumn{5}{|c|}{$1956-57$ crop } \\
\hline $\begin{array}{l}\text { Superphosphate } \\
\text { Hyperphosphate } \\
\text { Superphosphate plus lime } \\
\text { Hyperphosphate plus lime }\end{array}$ & $\begin{array}{r}3.00 \\
3.34 \\
1.13 \\
.96\end{array}$ & $\begin{array}{l}3.49 \\
3.75 \\
1.12 \\
2.36\end{array}$ & $\begin{array}{l}2.30 \\
2.18 \\
2.81 \\
2.44\end{array}$ & $\begin{array}{l}1.81 \\
1.92 \\
2.36 \\
2.47\end{array}$ \\
\hline
\end{tabular}

${ }^{1}$ No significant differences between treatment means.

TABLE 2.-Summary of the effect of liming acid Alonso clay upon yields of marketable coffee, 1953-57

\begin{tabular}{c|c|c|c|c}
\hline \multirow{2}{*}{ Crop } & \multicolumn{2}{|c|}{ Mean yields under indicated treatment } & \multicolumn{2}{|c}{ L.S.D. at level indicated } \\
\cline { 2 - 3 } & Unlimed & Limed & 5 percent & 1 percent \\
\hline & Cwt./A. & Cwt./A. & & \\
$1953-54$ & 6.83 & 6.89 & 1.25 & 1.69 \\
$1954-55$ & 1.77 & 1.32 & .72 & .95 \\
$1955-56$ & 8.34 & 6.70 & 2.07 & 2.74 \\
$1956-57$ & 2.65 & 1.85 & 1.32 & 1.75 \\
\hline
\end{tabular}


well supplied with available phosphorus, as shown in the following tabulation:

$\begin{array}{cr}\text { Depth in inches } & P_{2} O_{5}, l b . / A . \\ 0-6 & 18.3 \\ 6-12 & 16.5 \\ 12-18 & 11.0 \\ 18-30 & 7.4 \\ 30-42 & 36.6 \\ & \text { Total } 89.8\end{array}$

Coffee trees can obtain almost 35 pounds of available phosphorus from the upper acre-foot of this soil. Moreover, the 12- to 42-inch section of the profile can contribute an additional 55 pounds through the activity of feeding roots that penetrate to exploit a larger volume of soil. The profile as a whole can contribute a total of approximately 90 pounds to the acre, which seems to be more than ample for old coffee trees under the conditions prevalent in the experiment herein reported.

Thus, applications of phosphatic fertilizers to this soil are in all probability unnecessary, at least for the production of four crops of coffee, as shown under the experimental conditions herein reported. These data are in agreement with those of. McClelland (13), who did not obtain responses from phosphatic fertilization in the Mayagüez area. Gómez et al. (9) measured responses from phosphorus on Catalina clay in the Lares area. The difference in the phosphorus-supplying power of the soils, as well as the previous management of the groves, might account for such apparent discrepancies.

Studies (3) with superphosphate tagged with $\mathrm{P}^{32}$ applied to a nearby field of Alonso clay in the same Substation farm, indicated that the coffee trees absorbed most of the required phosphorus from the soil.

The application of lime at a rate of 4 tons to the acre produced no effects, either detrimental or beneficial, upon the yields of marketable coffee. These results are completely in agreement with those obtained by McClelland (13) in his liming experiments from 1913 to 1917 in the Mayagüez area. His results are summarized in the following tabulation, expressed as yields per tree, in liters:

$\begin{array}{ccc}\text { Year } & \text { Unlimed } & \cdot \\ 1914 & 1.23 & \text { Limed } \\ 1915 & 1.85 & 1.33 \\ 1916 & 1.33 & 1.55 \\ 1917 & 2.38 & 1.69 \\ & & 2.29\end{array}$

Other investigators $(5,6,7,8)$ obtained somewhat similar results to those mentioned previously when lime was applied to slightly acid soils. 
The same workers obtained increases in coffee yields following applications of 1 ton of lime to the acre to more acid soils, but failed to observe any effects when more lime was used.

The trees used in this work were old. Responses of young coffee trees to phosphoric acid were observed in a 3-year experiment at Mayagüez (9). However, the fact that Alonso clay appears to be well supplied with available phosphates might perhaps preclude any possibility of response to phosphatic fertilizers, even in young trees.

The use of lime in coffee groves is generally unnecessary unless high soil acidity develops, as when the pH values are in the vicinity of 4 or 4.5 . Even then lime seems beneficial only in small doses of 1 ton to the acre, the larger doses exerting no influence upon crop yields (8).

The shortcomings of this work-mainly arising from the use of old coffee trees and because of the fact that the Alonso clay is rather unusual among the soils whereon coffee is grown commercially because of its high fertility level-must be recognized. In spite of such limitations, the results obtained provide a key to what to expect from lime and phosphatic fertilization of old coffee groves established in Alonso clay soils.

\section{SUMMARY}

Data are reported here from a 4-year field experiment in an Alonso clay with old coffee trees in the vicinity of Adjuntas and Lares, in the heart of the Coffee Region of Puerto Rico. The experiment included super- and hyperphosphate applied either with or without lime, and at rates of 0,50 , 125, and 200 pounds to the acre. Lime was applied at a rate of 4 tons to the acre. No significant differences were measured in coffee yields which could be attributed to any of the treatments. These results are analyzed in the light of previous similar work. The general statement could be made that lime applications to acid Alonso clay soils do not affect the yields of coffee in any way, except perhaps when the acidity is high ( $\mathrm{pH} 4.0$ to 4.5), in which case applications of 1 ton are apparently sufficient. There is no need to apply phosphatic ferilizers to Alonso soils. However, the beneficial effects of these fertilizers have been demonstrated when dealing with other soils.

\section{RESUMEN}

Este trabajo presenta datos obtenidos de un experimento de campo que duró cuatro años y llevado a cabo en un suelo del tipo Alonso arcilloso con árboles viejos de café en la vecindad entre Adjuntas y Lares. Puede decirse que este sitio queda en el mismo centro de la zona cafetalera de Puerto Rico.

Los tratamientos a los cuales se sometió este campo experimental in- 
cluyeron el uso del superfosfato y el hiperfosfato, con y sin cal, en las proporciones siguientes: 0, 50, 125 y 200 libras por acre. La cal se aplicó a razón de 4 toneladas por acre.

No se obtuvieron diferencias significativas en los rendimientos de los árboles de café que pudieran atribuírse a los efectos de los distintos tratamientos. Estos resultados fueron analizados a la luz de los anteriormente obtenidos por otros investigadores de otros trabajos similares al que aquí se informa.

Se puede adelantar, en términos generales, que la aplicación de cal a suelos ácidos, como el Alonso arcilloso, no afecta significativamente los rendimientos de los árboles de café. Puede ser que en otros suelos mucho más ácidos (pH menor de 4.0 a 4.5) la aplicación de una tonelada de cal por acre, que sería más que suficiente, afectara favorablemente los rendimientos.

Se demostró que a suelos, como este Alonso arcilloso, no hay necesidad de aplicarles abonos fosfatados para aumentar los rendimientos del café, sin embargo, hay evidencia obtenida anteriormente que estos abonos han resultado beneficiosos cuando se han aplicado a otros suelos.

\section{LITERATURE CITED}

1. Bonnet, J. A., Lugo-López, M. A., Roldán, J., and Pérez-Escolar, R., Effect of lime and phosphate-bearing materials on sugarcane yields, J.Agr. Univ. P.R. 42 (1) 1-6, 1958.

2. Bonnet, J. A., Riera, A. R., and Roldán, J., Tracing the mineral from the soil to the plant, V: Effect of lime and phosphorus on Guinea, Merker, and ParaCarib grasses grown in association with tropical kudzu, J. Agr. Univ. P.R. 36 (2) $141-54,1952$.

3. $\_, \ldots$, and $\ldots$, Radioactive studies with $\mathrm{P}^{32}$ in tropical soils and crops of Puerto Rico, Soil Sci. Soc. Amer. Proc. 19 (3) 283-4, 1955.

4. Bonnet, J. A., Tirado-Sulsona, P., and Abruña, F., Effect of lime-phosphorius and green manure on sweetpotatoes and corn grown in acid soils, J. Agr. Univ. P. R. 31 (4) 303-21, 1947.

5. Guiscafré-Arrillaga, J., Univ. P. R. Agr. Exp. Sta. 1936-37 An. Rept., pp. 35-6, 1937.

6. Guiscafré-Arrillaga, J., and Gómez, L. A., Univ. P. R. Agr. Exp. Sta. 1938-39 An. Rept. pp. 72-3, 1939.

7. ___ and __, Univ. P. R. Agr. Exp. Sta. 1939-40 An. Rept. p. 36, 1940.

8. __ and __ Univ. P. R., Agr. Exp. Sta. 1940-41 An. Rept. p. 48, 1941.

9. Gómez, L. A., Lería-Esmoris, J., and Capó, B. G., Fertilizer requirements of coffee grown on Catalina clay in Puerto Rico, J. Agr. Univ. P.R. 30 (3) 127-37, 1946.

10. Jeffries, C. D., Bonnet, J. A., and Abruña, F., The constituent minerals of some soils of Puerto Rico, J. Agr. Univ. P.R. 37 (2) 114-39, 1953.

11. Lugo-López, M. A., Bonnet, J. A., and Pérez-Escolar, R., The effect of lime and synthetic soil conditioners on crop yields and soil aggregation, J. Agr. Univ. P.R. 41 (3) 179-88, 1957. 
12. McClelland, T. B., Some profitable and unprofitable coffee lands, P. R. (Federal) Agr. Exp. Sta. Bul. 21, 1917.

13. ___ Experiments with fertilizers for coffee in Porto Rico, P. R. (Federal) Agr. Exp. Sta. Bul. 31, 1926.

14. Olsen, S. R., Cole, C. V., Watanabe, F. S., and Dean, L. A., Estimation of available phosphorus in soils by extraction with sodium bicarbonate, USDA Cir. 939, 1954.

15. Roberts, R. C., Soil Survey of Puerto Rico, USDA in cooperation with Univ. P. R. Agr. Exp. Sta. Series 1936, No. 8, 1942. 